\title{
THE LOW-FODMAP DIET AS AN EFFECTIVE TOOL FOR MANAGING IRRITABLE BOWEL SYNDROME - AN ASSESSMENT OF ADULT PATIENTS' KNOWLEDGE OF DIETARY GUIDELINES
}

\author{
Matgorzata Kosteckal, Joanna Kostecka-Jarecka², Mariola Kowal ${ }^{3}$ \\ ${ }^{1}$ University of Life Sciences, Faculty of Food Science and Biotechnology, Lublin, Poland \\ ${ }^{2}$ Independent Public Healthcare Center in Łęczna, Łęczna, Poland \\ ${ }^{3}$ Voivodeship Specialist Hospital them. Stefan Cardinal Wyszyński, Independent Public Healthcare Center in Lublin, \\ Lublin, Poland
}

\begin{abstract}
Background. Irritable bowel syndrome (IBS) is the most common gastrointestinal disorder that is driven by the gutbrain axis and affects $1-20 \%$ of the population. Most patients note that various foods elicit abdominal symptoms, and they eliminate these products from their diets. A diet that is low in fermentable oligosaccharides, disaccharides, monosaccharides and polyols (FODMAP) is currently one of the mainstays in IBS treatment.

Objective. The aim of this study was to assess the knowledge of IBS patients about the disease, treatment and the principles of the low-FODMAP diet that can alleviate gastrointestinal symptoms.

Material and methods. The participants were adults diagnosed with IBS, the inclusion criteria were: absence of comorbidities requiring an elimination diet, age over 18 years, and consent to participate in the study. The respondents filled out an anonymous questionnaire containing questions about the IBS diagnosis, disease history and treatment, as well as 45 questions assessing the participants' knowledge about the low-FODMAP diet.

Results. In $28 \%$ of the cases, IBS was diagnosed by a general practitioner; in nearly $40 \%$ of the cases - by a gastroenterology specialist; in $10 \%$ of the cases - by a dietitian, whereas the remaining respondents had arrived at the diagnosis independently or with the help of support groups for IBS patients. After diagnosis, only every fourth respondent sought treatment in a gastroenterology clinic. In the studied population, 237 of the respondents had followed to the low-FODMAP diet, and the differentiating factors were sex $(\mathrm{p}=0.002)$, place of residence (city with a population higher than 100,000 vs. rural area; $\mathrm{p}=0.0001$ ) and education (university vs. vocational school $\mathrm{p}=0.0043$ ). Respondents who had been recently diagnosed with IBS (less than 12 months vs. more than 12 months before the study) were more likely to follow the FODMAP diet.

Conclusions. The surveyed population was characterized by high levels of knowledge about the low-FODMAP diet, but many respondents did not strictly comply with dietary guidelines, in particular the duration of each dietary phase. Age was significantly correlated with the respondents' knowledge, and the participants' familiarity with low-FODMAP guidelines decreased with age. Nutritional consultations did not significantly improve the respondents' knowledge about the low-FODMAP diet.
\end{abstract}

Key words: irritable bowel syndrome; low-FODMAP diet, fermentable carbohydrates, gastrointestinal symptoms

\section{STRESZCZENIE}

Wprowadzenie. Zespół jelita drażliwego (IBS- irritable bowel syndrome) określa się jako najczęstszą czynnościową chorobę przewodu pokarmowego występujący u około 1-20\% populacji. Większość pacjentów zauważa, że różne pokarmy wywołują objawy brzuszne i eliminują te produkty ze swojej diety. Dieta uboga w fermentujące oligosacharydy, disacharydy, monosacharydy i poliole (FODMAP) jest obecnie jednym ze sposobów leczenia IBS.

Cel. Celem przeprowadzonego badania była ocena wiedzy osób chorujących na zespół jelita drażliwego na temat samej choroby, jej leczenia i postępowania żywieniowego z zastosowaniem diety o niskiej zawartości FODMAP, które może przyczyniać się do łagodzenia objawów.

Materiały i metody. W badaniu wzięły udział osoby ze zdiagnozowanym zespołem jelita drażliwego, kryterium włączenia do badań był brak innych chorób wymagających stosowania diety eliminacyjnej, wiek powyżej 18 lat oraz wyrażona zgoda na udział w badaniach. Wykorzystano anonimowy kwestionariusz ankiety zawierający metryczkę dotyczącą diagnozowania choroby, jej przebiegu i leczenia, oraz część właściwą składającą się z 45 pytań dotyczących wiedzy na temat diety low-FODMAP.

Corresponding author: Małgorzata Kostecka, University of Life Sciences, Faculty of Food Science and Biotechnology, 15 Akademicka Street, 20-950 Lublin, Poland, phone number: +48 81 445-68-46; e-mail: kostecka.malgorzata@gmail.com.

(C) Copyright by the National Institute of Public Health NIH - National Research Institute 
Wyniki. Diagnozę u 28\% pacjentów postawił lekarz rodzinny, w prawie 40\% przypadków lekarz gastroeneterolog, u co 10 osoby dietetyk, a pozostałe osoby zdiagnozowały się samodzielnie lub na grupach wsparcia dla osób z IBS. Po rozpoznaniu choroby tylko co 4 chory deklarował, że jest pod opieką poradni gastroenterologicznej. Respondenci jako jedną z metod leczenia stosowali dietę o niskiej zawartości FODMAP, taki sposób leczenia żywieniowego wskazało 237 osób, czynnikami różnicującymi była płeć ( $\mathrm{p}=0.002$ ), miejsce zamieszkania (miasto powyżej 100 tysięcy mieszkańców vs wieś, $p=0.0001$ ) i wykształcenie (wyższe vs zawodowe, $p=0.0043$ ). Dietę low-FODMAP częściej stosowały osoby, u których niedawno rozpoznano IBS (poniżej $12 \mathrm{~m}$-cy od diagnozy vs powyżej $12 \mathrm{~m}$-cy).

Wnioski. Wiedza na temat diety low-FODMAP w badanej populacji była dobra, ale jej zastosowanie w praktyce w wielu przypadkach było błędne, szczególnie w zakresie długości trwania etapów diety. Wiek był istotnie statystycznie powiązany z poziomem wiedzy, im wyższy wiek ankietowanych tym niższa wiedza na temat diety w IBS. Opieka dietetyka podczas stosowania diety o niskiej zawartości FODMAP nie wpłynęła znacząco na poziom wiedzy respondentów.

Słowa kluczowe: zespót jelita drażliwego; dieta low-FODMAP; węglowodany łatwofermentujące; objawy żołądkowojelitowe.

\section{INTRODUCTION}

Irritable bowel syndrome (IBS) is the most common gastrointestinal disorder that is driven by the gut-brain axis and affects $1-20 \%$ of the population. In North America, IBS is diagnosed in $5-10 \%$ of the population, and it is three to four times more prevalent in women [1,17]. In Poland, up to $13 \%$ of the adult population may be affected by IBS, and gut motility disorders are the most prevalent condition diagnosed in gastroenterological patients (up to $50 \%$ of the cases) [1]. Half of the patients experience the first symptoms before the age of 35, and the prevalence of IBS in this age group is $25 \%$ higher than among patients older than 50 [21]. Around 5-6\% of the affected population meet Rome IV Criteria for the diagnosis of IBS, including recurrent abdominal pain at least 1 day per week during the previous three months on average, with onset at least six months previously $[1,13,18,28]$.

Irritable bowel syndrome is a chronic disease, and symptoms can recur throughout the patient's life. Effective management of IBS requires a correct diagnosis and the patient's cooperation with a physician, dietitian and, in some cases, a psychotherapist [1].

Pharmaceuticals such as bulking agents, anticholinergics, antispasmodics and antidiarrheals are mostly ineffective in IBS treatment, and many gastroenterologists recommend dietary management $[14,15]$. In addition to dietary changes, the use of peppermint oil preparations is recommended to reduce IBS symptoms [29]. Most patients note that various foods elicit abdominal symptoms, and they eliminate these products from their diets. A diet that is low in fermentable oligosaccharides, disaccharides, monosaccharides and polyols (FODMAP) is currently one of the mainstays in IBS treatment $[4,9,29]$. These compounds can lead to osmotic stress, increased water absorption, intestinal wall stretching and pain. They are fermented by intestine bacteria which produce excess gas [19]. In the low-FODMAP diet, these products are eliminated or restricted to minimize symptoms, and the patient's individual response is assessed.

The aim of this study was to assess the knowledge of IBS patients about the disease, treatment and the principles of the low-FODMAP diet that can alleviate gastrointestinal symptoms.

\section{MATERIAL AND METHODS}

\section{Study site and period}

The study was conducted in Poland between January and June 2020.

\section{Methods}

The participants were adults diagnosed with IBS who were members of patient support groups on Facebook and Instagram as well as patients of the nutrition clinic at the University of Life Sciences in Lublin. The inclusion criteria were: confirmed diagnosis of IBS, absence of comorbidities requiring an elimination diet, age over 18 years, and consent to participate in the study.

The respondents filled out an anonymous questionnaire containing questions about the IBS diagnosis, disease history and treatment, as well as 45 questions assessing the participants' knowledge about the low-FODMAP diet (fermentable oligosaccharides, disaccharides, monosaccharides and polyols; their dietary sources and impact on IBS symptoms), dietary habits, lifestyle and well-being during treatment. The questionnaire contained single- and multiplechoice closed-ended questions as well as open-ended questions. A total of 336 respondents completed the questionnaire, and 259 correctly filled out questionnaires were returned and used in the analysis.

\section{Statistical analysis}

A total of 259 correctly filled out questionnaires were returned, and the resulting data were subjected to mathematical and statistical analyses in the Statistica 10 program. The relationship between the 
respondents' knowledge about the low-FODMAP diet and environmental factors was evaluated by calculating Spearman's rank correlation coefficients. The odds ratios (ORs) and 95\% confidence intervals (95\% CIs) were calculated. The significance of ORs was assessed by Wald's statistics. The levels of statistical significance were set at $\mathrm{P}<0.05(*), \mathrm{P}<$ $0.01(* *)$ and $\mathrm{P}<0.001\left(^{* * *}\right)$. The Shapiro-Wilk test was used to test the normality of distributions. The average nutritional status of groups was compared in ANOVA, and frequency distributions were evaluated in Pearson's chi-squared $\left(\chi^{2}\right)$ test. Two-tailed p-values $<0.05$ were considered statistically significant in all tests. Analyses were performed using Statistica software (version 13.1 PL; StatSoft Inc., Tulsa, OK, USA; StatSoft, Krakow, Poland).

\section{RESULTS}

A total of 195 women (75.3\%) participated in the study (Table 1). The average BMI in the surveyed population was $23.17 \pm 5.04 \mathrm{~kg} / \mathrm{m}^{2}\left(\min -17.8 \mathrm{~kg} / \mathrm{m}^{2}\right.$, $\max -38.54 \mathrm{~kg} / \mathrm{m}^{2}$ ). The average BMI was significantly lower among female $\left(22.61 \mathrm{~kg} / \mathrm{m}^{2}\right)$ than male $(26.8 \mathrm{~kg} /$ $\left.\mathrm{m}^{2}\right)$ respondents $(\mathrm{p}=0.001)$. Normal BMI values were significantly more often noted among respondents who resided in cities with a population higher than $100,000(p<0.05)$, had university education $(p<0.05)$ and had been diagnosed with IBS 3-9 months before the study $(\mathrm{p}<0.05)$. A significantly higher number of overweight participants had been diagnosed with IBS several years before the study $(p<0.05)$ and had secondary school education $(p<0.05)$. In the studied population, the average time since IBS diagnosis was 4 years and 3 months (minimum - 7 months, maximum - more than 10 years in a 46-year-old male patient). In $28 \%$ of the cases, IBS was diagnosed by a general practitioner; in nearly $40 \%$ of the cases - by a gastroenterology specialist; in $10 \%$ of the cases by a dietitian, whereas the remaining respondents had arrived at the diagnosis independently or with the help of support groups for IBS patients. After diagnosis, only every fourth respondent sought treatment in a gastroenterology clinic (most of these patients had been diagnosed in the previous 12 months; $p<0.05$ ), whereas only $20 \%$ of the respondents had consulted a dietitian. Most participants sought additional information about IBS and disease management on the Internet or among friends.

The respondents assessed their health status subjectively, and the results revealed that their subjective well-being improved with an increase in the length of time since diagnosis $(p=0.002)$ and that disease symptoms were less likely to exert a negative impact on their quality of life. Nearly a third of the surveyed subjects were physically active and engaged in recreational activities such as Nordic walking, jogging and cycling. More than $75 \%$ of the respondents used dietary supplements to boost immunity and improve digestive function. The use

Table 1. Description of the study group

\begin{tabular}{|c|c|c|c|}
\hline & Women $(\mathrm{n}=195)$ & Men $(\mathrm{n}=64)$ & $\mathrm{p}$-value \\
\hline Age & & & $\mathrm{ns}$ \\
\hline $18-30$ & 106 & 34 & \\
\hline $31-65$ & 89 & 3 & \\
\hline BMI $\left.\mathbf{( k g} / \mathbf{m}^{2}\right)$ & 15 & 37 & \\
\hline$<19.99$ & 157 & 24 & $\mathrm{~ns}$ \\
\hline $20-24.99$ & 23 & & \\
\hline$>25$ & & 39 & \\
\hline Education & 150 & 11 & \\
\hline University & 32 & 14 & \\
\hline Secondary school & 13 & & \\
\hline Vocational school & & 26 & \\
\hline Place of residence & 111 & 26 & \\
\hline City $>100,000$ & 50 & 12 & \\
\hline City $<100,000$ & 34 & & \\
\hline Rural area & & 28 & \\
\hline Time since diagnosis & 73 & 25 & \\
\hline$<12$ months & 42 & 11 & \\
\hline $13-24$ months & & & \\
\hline$>24$ months & & & \\
\hline
\end{tabular}




\title{
Circumstances in which symptoms were most frequently experienced
}

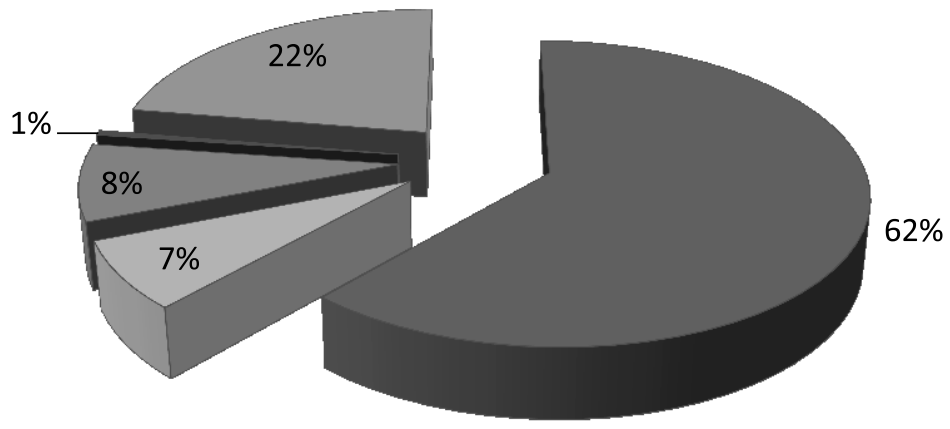

\author{
After a meal \\ $\square$ During defecation \\ $\square$ Before going to sleep \\ At night \\ $\square$ in the morning, immediately \\ after waking
}

Figure 1. Symptoms experienced before diagnosis/treatment

of dietary supplements was highest among women younger than $30(p<0.05)$ who were overweight and had university education $(\mathrm{p}<0.05)$. The most popular dietary supplements were herbal blends and herbs such as lemon balm, mint, chamomile, oak bark and yarrow, as well as vitamin and mineral supplements. Nearly every seventh participant had been prescribed a course of antibiotics unrelated to IBS at least once a year (not all antibiotic therapies were combined with probiotic supplementation), which gives serious cause for concern. Pharmacotherapy was effective in less than $50 \%$ of the surveyed population: it eliminated bloating in $60 \%$ of the cases, relieved constipation in $1 / 3$ of the cases, and eliminated diarrhea in $44 \%$ of the cases.

The symptoms experienced by the patients before diagnosis were analyzed in the next stage of the study. The majority of the respondents had experienced digestive symptoms, mostly diarrhea (64\%) and constipation (59\%). The studied population represented all IBS sub-types classified based on the predominant stool pattern according the Bristol Stool Form Scale (124 diarrhea-predominant patients, 75 constipationpredominant patients, 41 mixed-type patients, whereas the remaining patients were unsubtyped).

In the studied population, $85 \%$ of the participants had experienced bloating, and more than $75 \%$ - stomach growling. Other symptoms, including flatulence, nausea, weight loss and fatigue, were also reported. In most cases, these symptoms were experienced under the specific circumstances described in the literature (Figure 1), mainly in the first half of the day, after waking and after eating a meal, often after breakfast $(p=0.001)$ or a large meal consumed during the day $(\mathrm{p}=0.004)$.

In the studied population, 237 of the respondents had followed to the low-FODMAP diet, and the differentiating factors were sex $(\mathrm{p}=0.002)$, place of residence (city with a population higher than 100,000 vs. rural area; $p=0.0001$ ) and education (university vs. vocational school $\mathrm{p}=0.0043$ ). The remaining participants eliminated various foods from their diets, but they did not strictly comply with FODMAP guidelines, and some foods were eliminated on several occasions or over a period of several weeks/months.

Respondents who had been recently diagnosed with IBS (less than 12 months vs. more than 12 months before the study) and who had consulted a dietitian were more likely to follow the low-FODMAP diet (Table 2).

A sound knowledge of food products that should be eliminated from the diet, adherence to the prescribed dietary regimen and the reintroduction of selected food products play an important role in the low-FODMAP diet. The respondents' overall knowledge of the low-FODMAP diet was calculated as the percentage of correct answers in the questions addressing the low-FODMAP diet. The percentage of

Table 2. The relationship between adherence to the low-FODMAP diet and population characteristics based on the results of the $C h i$-squared test

\begin{tabular}{|c|c|c|c|c|c|}
\hline & & $\chi^{2}$ & df & $\mathrm{p}$ & $\mathrm{V}$ \\
\hline \multirow{3}{*}{$\begin{array}{c}\text { Do you follow the low- } \\
\text { FODMAP diet? }\end{array}$} & Sex & 0.03 & 1 & 0.867 & 0.01 \\
\cline { 2 - 7 } & Education & 7.30 & 3 & 0.063 & 0.19 \\
\cline { 2 - 7 } & Time since diagnosis & 12.60 & 2 & 0.002 & 0.25 \\
\cline { 2 - 7 } & Have you consulted a dietitian? & 7.75 & 1 & 0.005 & 0.19 \\
\hline
\end{tabular}

$\chi^{2}$ - Chi-square statistic, $d f$ - degrees of freedom, $p$ - level of significance, $V$-Cramer's $\mathrm{V}$ 
correct answers ranged from $38.46 \%$ to $100 \%(77.01 \%$ $\pm 11.49 \%$ on average), and every third respondent correctly answered at least $80 \%$ of the questions. Age was significantly correlated with the participants' knowledge about the low-FODMAP diet, which was found to decrease with age. The respondents' knowledge was not differentiated by education, time since diagnosis, BMI or subjective well-being $(\mathrm{p}>0.05)$.

An analysis of the results (Table 3) indicates that consultations with a dietitian did not affect the respondents' knowledge about the low-FODMAP diet. This observation was further confirmed by the fact that the surveyed subjects sought additional information about the disease on the Internet or among friends, and only every fifth participant had consulted a dietitian.

The consumption of fermentable carbohydrates, including monosaccharides, disaccharides, oligosaccharides and polysaccharides, is limited or eliminated in the low-FODMAP diet. A sound knowledge of food products containing these compounds is required for the low-FODMAP diet to be administered safely and effectively (Table 4).

The respondents found it most difficult to correctly identify the dietary sources of oligosaccharides and polyols. More than half of the surveyed subjects were unaware that garlic and onions contain oligosaccharides, and that these products should not be consumed by IBS patients. More than 50\% of the participants were also unaware that artificial sweeteners, chewing gum and mushrooms contain polyols.

Half of the respondents who followed the lowFODMAP diet adhered to this dietary regime only once, and the elimination phase lasted 4 weeks and 3 days on average (minimum -3 weeks, maximum - more than 9 weeks). The reintroduction phase lasted 11 weeks and 2 days on average (maximum -

Table 3. Analysis of the correlations between the respondents' knowledge about the low-FODMAP diet, adherence to the dietary regimen, consultations with a dietitian, physical activity and pharmacotherapy

\begin{tabular}{|c|c|c|c|c|c|c|}
\hline \multirow{2}{*}{ Level of knowledge } & \multicolumn{2}{|c|}{ No } & \multicolumn{2}{|c|}{ Yes } & \multirow{2}{*}{ Z } & \multirow{2}{*}{$\mathrm{p}$} \\
\hline & $\mathrm{M}[\%]$ & SD [\%] & $\mathrm{M}[\%]$ & SD [\%] & & \\
\hline $\begin{array}{l}\text { Do you follow the low-FODMAP } \\
\text { diet? }\end{array}$ & 72.65 & 13.14 & 80.13 & 8.97 & 4.13 & 0.000 \\
\hline $\begin{array}{l}\text { Have you consulted a dietitian } \\
\text { after diagnosis? }\end{array}$ & 76.89 & 11.02 & 77.42 & 13.11 & 0.65 & 0.518 \\
\hline Are you physically active? & 77.98 & 11.06 & 76.47 & 11.72 & 0.81 & 0.416 \\
\hline $\begin{array}{l}\text { Do you take any medication } \\
\text { approved for IBS? }\end{array}$ & 76.64 & 11.46 & 77.37 & 11.56 & 0.26 & 0.793 \\
\hline
\end{tabular}

$M$ - mean, $S D$ - standard deviation, Z-Z-score in the Mann-Whitney U-test, $p$ - level of significance

Table 4. Correlation between the respondents' age and time since diagnosis vs. their knowledge of fermentable carbohydrates that are eliminated in the FODMAP diet

\begin{tabular}{|c|c|c|c|c|c|}
\hline & \multicolumn{4}{|c|}{ Level of knowledge* (max 5 points) } & \multirow[b]{2}{*}{$\begin{array}{c}\text { Dietary } \\
\text { guidelines (max } \\
20 \text { points) }\end{array}$} \\
\hline & $\begin{array}{l}\text { Monosaccharides } \\
\text { and their food } \\
\text { sources }\end{array}$ & $\begin{array}{l}\text { Disaccharides } \\
\text { and their food } \\
\text { sources }\end{array}$ & $\begin{array}{l}\text { Oligosaccharides } \\
\text { and their food } \\
\text { sources }\end{array}$ & $\begin{array}{l}\text { Polyols and their } \\
\text { food sources }\end{array}$ & \\
\hline \multicolumn{6}{|c|}{ Age } \\
\hline $18-30$ & 4.2 & 4.5 & 3.9 & 3.3 & 18.4 \\
\hline $31-65$ & 3.8 & 3.7 & 1.8 & 2.1 & 13.6 \\
\hline Difference & 0.4 & 0.8 & 2.1 & 1.2 & 4.8 \\
\hline$p$-value & $>0.05$ & $<0.05$ & $<0.01$ & $<0.05$ & $<0.01$ \\
\hline \multicolumn{6}{|c|}{ Time since diagnosis } \\
\hline$<12$ months & 4.4 & 4.7 & 2.6 & 3.1 & 16.9 \\
\hline 13-24 months & 4.0 & 4.2 & 3.3 & 3.3 & 18.7 \\
\hline$>24$ months & 4.1 & 4.0 & 4.0 & 2.9 & 17.3 \\
\hline Difference & 0.4 & 0.7 & 1.4 & 0.4 & 1.8 \\
\hline$p$-value & $>0.05$ & $<0.05$ & $<0.05$ & $>0.05$ & $>0.05$ \\
\hline
\end{tabular}

* expressed as the average number of points in the knowledge test (separately for each carbohydrate group that is eliminated in the low-FODMAP diet) 
18 weeks). The remaining respondents skipped the elimination phase (17\%) or prolonged the elimination phase beyond 6 weeks, mainly due to the fear of symptom recurrence. The participants who did not strictly comply with low-FODMAP guidelines had never consulted a dietitian or had attended only one consultation after diagnosis.

\section{DISCUSSION}

The low-FODMAP diet should be introduced only once during treatment as the first-line therapy for IBS. The diet should involve a personalized eating plan to eliminate all IBS symptoms. The low-FODMAP is not a life-long diet, and the entire therapeutic program should be supervised by an experienced dietitian $[7,12,24]$. In the studied population, only $20 \%$ of the respondents adhering to the elimination diet had consulted a dietitian, and in this group, only 36 individuals had regularly visited a nutrition clinic during the entire treatment and the reintroduction phase. The skills of a dietitian in dietary assessment, knowledge of FODMAP food composition and experience with the low-FODMAP dietary approach are likely to impact on the success of the diet $[2,26,30]$. Experience in gastrointestinal disorder management, consideration of symptom types, severity, baseline FODMAP intake, and overall nutritional content and meal pattern are vital in the assessment. If a strict low-FODMAP diet is deemed necessary, it should only be introduced for an initial period of 4 to 6 weeks. Research suggests that a strict long-term, lowFODMAP diet may negatively impact the intestinal microbiome, and if it is used for a long time - it is a diet that exposes the patient to a deficiency of vitamins and minerals.

The low-FODMAP diet is an effective tool in IBS management. In the studied population, $75 \%$ of the respondents who had followed the low-FODMAP diet reported a decrease or complete disappearance of symptoms associated with IBS such as abdominal pain, flatulence, diarrhea and stomach growling. Similar results were reported by Halmos [9] in the Australian population, by Staudacher [25] in the British population, and by Gibson [7], in whose study, IBS symptoms significantly subsided in $70-75 \%$ of the respondents who adhered to the low-FODMAP diet for 6 weeks.

The main goal of the elimination phase of the lowFODMAP diet is to silence the symptoms of disease. In the next stage, selected foods are reintroduced to identify products rich in fermentable carbohydrates that are tolerated by the patient. In the studied population, nearly $25 \%$ of the participants delayed the reintroduction phase in fear of symptom recurrence. The long-term goal of low-FODMAP diet education is to reintroduce high-FODMAP foods to personal tolerance [2]. Recent research has highlighted the potential negative impact of a strict low-FODMAP diet on the intestinal microbiome $[8,25]$. Therefore, the restrictive phase of the diet should only be continued until symptoms improve, usually within 4-6 weeks. There is evidence to suggest that prolonged adherence to a restrictive elimination diet can increase the risk of eating disorders [23]. Dunn and Bratman [5] hypothesized that in patients with good dietary management and disordered eating, gastrointestinal symptoms may create food aversion and cause alterations to eating patterns. Such behaviors have recently been linked to orthorexia nervosa, a condition in which people restrict their diet. This condition is associated with symptoms such as an "obsessive focus on food choice, planning, purchase, preparation, and consumption; food regarded primarily as [a] source of health rather than pleasure; [and] exaggerated faith that inclusion or elimination of particular kinds of food can prevent or cure disease or affect daily well-being" [23]. In this study, eating disorders were reported by 15 respondents, most of whom had been diagnosed with IBS in the previous 6 months (more than 3 months after the first symptoms) and who belonged to the diarrhea-predominant subtype of IBS.

Fructans and galacto-oligosaccharides have prebiotic properties. A reduction in their intake can decrease bacterial counts of the genera Lactobacillus and Bifidobacterium in the gut microbiome [8, 10, $20,22]$. Furthermore, the production of butyrateproducing bacteria is markedly reduced in absolute and relative terms, and the counts of mucus-degrading bacteria are increased with a strict reduction in FODMAP intake [11]. In the present study, more than $90 \%$ of the participants were aware that gut microbiota can affect IBS, and $50 \%$ of the respondents took dietary supplements containing probiotic bacteria, mostly Lactobacillus rhamnosus GG, Saccharomyces cerevisiae and Bifidobacterium longum W11. The results of clinical trials comparing the efficacy of single- and multi-strain probiotics are ambiguous [6]. The British Dietetic Association published a systematic review which indicated that no strain or dose-specific probiotic was consistently effective in improving any IBS symptoms or the quality of life (QoL) [16]. Tiequn et al. [27] reported that Lactobacillus strains were more effective than placebo, whereas CayzeeleDecherf et al. [3] concluded that Saccharomyces cerevisiae CNCM I-3856 significantly minimized abdominal pain and discomfort in IBS patients. In contrast, a meta-analysis conducted by Yuan et al. [31] demonstrated that Bifidobacterium infantis 35624 was not more effective than placebo in alleviating IBS symptoms. 


\section{CONCLUSIONS}

The surveyed population was characterized by high levels of knowledge about the low-FODMAP diet, but many respondents did not strictly comply with dietary guidelines, in particular the duration of each dietary phase.

Age was significantly correlated with the respondents' knowledge, and the participants' familiarity with FODMAP guidelines decreased with age.

Nutritional consultations did not significantly improve the respondents' knowledge about the lowFODMAP diet.

The low-FODMAP diet can be an effective tool for managing irritable bowel syndrome, but patients who do not fully comply with FODMAP guidelines are at higher risk of malnutrition or even eating disorders. Prolonged elimination of cereal-based products, dairy products, legumes, fruit and vegetables can alleviate the symptoms of diseases, but it can also compromise the patients' health.

\section{Conflict of interest}

The authors declare no conflict of interest.

\section{REFERENCES}

1. Adrych K.: Zespół jelita drażliwego w świetle najnowszych wytycznych. Forum Medycyny Rodzinnej 2018;12(6):224-233.

2. Barrett J.S.: How to institute the low-FODMAP diet. J Gastroenterol Hepatol 2017;32(1):8-10. doi: 10.1111/ jgh.13686.

3. Cayzeele-Decherf A., Pelerin F., Leuillet S., Douillard B., Housez B., Cazaubiel M., Jacobson G.K., Jüsten P., Desreumaux P.: Saccharomyces cerevisiae CNCM I-3856 in irritable bowel syndrome: an individual subject meta-analysis. World J Gastroenterol 2017;23(2):336344. doi:10.3748/wjg.v23.i2.336

4. Dionne J., Ford A., Yuang Y., Chey W., Lacy B., Saito Y., Quigley E..M.M., Moayyedi P.: A systematic review and meta-analysis evaluating the efficacy of a gluten-free diet and a low FODMAPS diet in treating symptoms of irritable bowel syndrome. Am J Gastroenterol 2018;113/:1290-1300. doi: 10.1038/s41395-018-0195-4.

5. Dunn T.M., Bratman S.: On orthorexia nervosa: A review of the literature and proposed diagnostic criteria. Eat Behav 2016;21:11-17. doi: 10.1016/j.eatbeh.2015. 12.006.

6. Ford A.C., Harris L.A., Lacy B.E., Quigley E.M.M., Moayyedi P.: Systematic review with meta-analysis: the efficacy of prebiotics, probiotics, synbiotics and antibiotics in irritable bowel syndrome Aliment Pharmacol Ther 2018;48(10):1044-1060. doi: 10.1111/ apt.15001

7. Gibson P.R.: The evidence base for efficacy of the low FODMAP diet in irritable bowel syndrome: is it ready for prime time as a first-line therapy? J Gastroenterol Hepatol 2017;32(1):32-35. doi: 10.1111/jgh.13693.

8. Halmos E.P., Christophersen C.T., Bird A.R., Shepherd S.J., Gibson P.R., Muir J.G.: Diets that differ in their FODMAP content alter the colonic luminal microenvironment. Gut 2015; 64(1): 93-100. doi: 10.1136/gutjnl-2014-307264.

9. Halmos E.P., Power V.A., Shepherd S.J., Gibson P.R., Muir J.G.: A diet low in FODMAPs reduces symptoms of irritable bowel syndrome. Gastroenterology 2014; 146(1):67-75.e5. doi: 10.1053/j.gastro.2013.09.046.

10. Harper A., Naghibi M.M., Garcha D.: The role of bacteria, probiotics and diet in irritable bowel syndrome. Foods 2018; 7(2): 13 doi: 10.3390/foods7020013

11. Hill P., Muir J.G., Gibson P.R.: Controversies and Recent Developments of the Low-FODMAP Diet. Gastroenterol Hepatol (N Y) 2017;13(1):36-45.

12. Ireton-Jones C., Weisberg M.F.: Management of Irritable Bowel Syndrome: Physician-Dietitian Collaboration. Nutr Clin Pract 2020; 35(5):826-834. doi: 10.1002/ncp.10567.

13. Jossan N., Simren M., Sperber A.: Health care utilization for Rome IV irritable bowel syndrome; a three-country survey in the general population. Gastroenterology 2017;152: S68.

14. Krieger-Grübel C., Hutter S., Hiestand M., Brenner I., Güsewell S., Borovicka J.: Treatment efficacy of a low FODMAP diet compared to a low lactose diet in IBS patients: A randomized, cross-over designed study. Clin Nutr ESPEN 2020;40:83-89. doi: 10.1016/j. clnesp.2020.09.020.

15. Lenhart A., Ferch C., Shaw M., Chey $W$.: Use of dietary management in irritable bowel syndrome: results of a survey of over 1500 U.S. Gastroenterologists J Neurogastroenterol Motil 2018;24:437-451.

16. McKenzie Y.A. , Thompson J., Gulia P., Lomer M.C.E.: British Dietetic Association systematic review of systematic reviews and evidence-based practice guidelines for the use of probiotics in the management of irritable bowel syndrome in adults (2016 update) J Hum Nutr Diet 2016; 29(5): 576-592. doi: 10.1111/jhn.12386

17. Mearin F., Lacy B.E., Chang L., Chey W.D., Lembo A.J., Simren M., Spiller R.: Bowel Disorders. Gastroenterology 2016;S0016-5085(16)00222-5. doi: 10.1053/j.gastro.2016. 02.031.

18. Mulak A., Smereka A., Paradowski L.: Nowości i modyfikacje w Kryteriach Rzymskich IV. Gastroenterologia Kliniczna 2016; 8(2): 58-59.

19. Murray K., Wilkinson-Smith V., Hoad C., Costigan C., Cox E., Lam C., Marciani L., Gowland P., Spiller R.C.: Differential effects of FODMAPs (Fermentable Oligo-, Di-, Mono-Saccharides and Polyols) on small and large intestinal contents in healthy subjects shown by MRI. Am J Gastroenterol 2014;109:110-119. doi: 10.1038/ajg.2013.386.

20. Parkes G.C., Rayment N.B., Hudspith B.N., Petrovska L., Lomer M.C., Brostoff J., Whelan K., Sanderson J.D.: Distinct microbial populations exist in the mucosaassociated microbiota of sub-groups of irritable bowel 
syndrome. Neurogastroenterol Motil 2012;24(1):31-39. doi: 10.1111/j.1365-2982.2011. 01803.x.

21. Pietrzak A., Skrzydło-Radomańska B., Mulak A., Lipiński M., Małecka-Panas E., Reguła J., Rydzewska G.: Rekomendacje diagnostyczno-terapeutyczne w zespole jelita nadwrażliwego. Gastroenterology Rev 2018;13(4):167-196. doi: 10.5114/pg.2018.78343.

22. Principi N., Cozzali R., Farinelli E., Brusaferro A., Esposito S.: Gut dysbiosis and irritable bowel syndrome: the potential role of probiotics. J Infect 2018;76(2):111-120, doi: 10.1016/j.jinf.2017.12.013

23. Satherley R., Howard R., Higgs S.: Disordered eating practices in gastrointestinal disorders. Appetite 2015;84:240-250. doi: 10.1016/j.appet.2014.10.006.

24. Scarlata K., Catsos P., Smith J.: From a dietitian's perspective, diets for irritable bowel syndrome are not one size fits all. Clinical Gastroenterol Hepatol 2020; 18(3): 543- 545.

25. Staudacher H.M., Lomer M.C., Anderson J.L., Barrett J.S., Muir J.G., Irving P.M., Whelan K.: Fermentable carbohydrate restriction reduces luminal bifidobacteria and gastrointestinal symptoms in patients with irritable bowel syndrome. J Nutr 2012;142(8):1510-1518. doi: 10.3945/jn.112.159285.

26. Staudacher H.M., Whelan K., Irving P.M., Lomer M.C.: Comparison of symptom response following advice for a diet low in fermentable carbohydrates (FODMAPs) versus standard dietary advice in patients with irritable bowel syndrome. J Hum Nutr Diet 2011;24(5):487-495. doi: 10.1111/j.1365-277X.2011.01162.x.

27. Tiequn B., Guanqun C., Shuo Z.: Therapeutic effects of Lactobacillus in treating irritable bowel syndrome: a meta-analysis. Intern Med 2015;54(3):243249. doi:10.2169/internalmedicine.54.2710
28. Van den Houte K., Carbone F., Pannemans J., Corsetti M., Fischler B., Piessevaux H., Tack J.: Prevalence and impact of self-reported irritable bowel symptoms in the general population. United European Gastroenterol J 2018;7:307-315. doi: 10.1177/2050640618821804.

29. Weerts Z.Z.R.M., Masclee A.A.M., Witteman B.J.M., Clemens C.H.M., Winkens B., Brouwers J.R.B.J., Frijlink H.W., Muris J.W.M., de Wit N.J., Essers B.A.B., TackJ., Snijkers J.T.W., Bours A.M.H., de Ruiter-van der Ploeg A.S., Jonkers D.M.A.E., Keszthelyi D.: Efficacy and Safety of Peppermint Oil in a Randomized, DoubleBlind Trial of Patients With Irritable Bowel Syndrome. Gastroenterology 2020;158(1):123-136. doi: 10.1053/j. gastro. 2019.08.026.

30. Whigham L., Joyce T., Harper G., Irving P.M., Staudacher H.M., Whelan K., Lomer M.C.: Clinical effectiveness and economic costs of group versus one-to-one education for short-chain fermentable carbohydrate restriction (low FODMAP diet) in the management of irritable bowel syndrome. J Hum Nutr Diet 2015;28(6):687-696. doi: 10.1111/jhn.12318.

31. Yuan F., Ni H., Asche C.V., Kim M., Walayat S., Ren $J .:$ Efficacy of Bifidobacterium infantis 35624 in patients with irritable bowel syndrome: a metaanalysis. Curr Med Res Opin 2017;33(7):11911197. doi:10.1080/03007995.2017.1292230.

Received: 23.07.2021

Accepted: 17.09.2021

Published online first: 22.09.2021 